\title{
Economic Importance and Widespread of Ectoparasites Infestation in Indigenous Chickens (Gallus gallus domesticus). A Study from Selected Local Government Councils and States in Nigeria.
}

\section{Importancia económica y generalización de la infestación de ectoparásitos en pollos indígenas (Gallus gallus domesticus). Un estudio de los consejos de gobiernos locales seleccionados y estados en Nigeria.}

\author{
Ahaotu, E.O'1*, A. Akinfemi² and Okorie, K.C 3 . \\ ${ }^{1 *}$ Department of Animal Production Technology, Imo State Polytechnic Umuagwo, Nigeria. \\ ${ }^{2}$ Department of Agricultural Technology, Yaba College of Technology Epe Campus, Lagos State, \\ Nigeria. \\ ${ }^{3}$ Department of Animal Science and Fisheries, Imo State University, Owerri, Nigeria. \\ Corresponding author: Ahaotu, E.O; *emmaocy@yahoo.com. +234-803-8520777.
}

\begin{abstract}
A cross sectional study was conducted from June 2016 to August 2017 to identify the widespread of ectoparasites in indigenous chickens and its associated economic significance in randomly selected Local Government Councils and States in Nigeria. A total of 1025 indigenous chickens were examined out of which $90.7 \%$ were infested with one or more ectoparasites species. Four types of ectoparasites genera were encountered in this study, $17.0 \%$ of the total chickens examined were infested with only one genera while $73.9 \%$ were infested with two or more different genera. Among the ectoparasites encountered, lice infestation (85.8\%) was the most prevalent followed by mite $(70.4 \%)$, Flea $(27.3 \%)$ and tick $(6.2 \%)$ in descending order of widespread. Ten different species of ectoparasites, namely Menopon gallinae, Lipeurus caponis, Goniodes gigas, Cnemidocoptes mutans, Dermanyssus gallinae, Epidermoptes species, Laminosioptes cysticola, Megninia species, Echidnophaga gallinacean and Argas persicus were identified in the study. Menopon gallinae (50\%) was most frequently encountered while Megninia species $(2.7 \%)$ was least prevalent. The findings of this study showed that ectoparasites infestations were highly prevalent among indigenous chicken flocks, which may
\end{abstract}


likely affect their optimum productivity. Routine prevention and control of ectoparasites should be encouraged in the study areas.

Key Words: Indigenous chickens, ectoparasites, infestations, selected local government councils and states in Nigeria.

\section{RESUMEN}

Se realizó un estudio transversal de junio de 2016 a agosto de 2017 para identificar la propagación de ectoparásitos en pollos nativos y su significado económico asociado en los Consejos de Gobierno Local seleccionados al azar y en los Estados de Nigeria. Se examinaron un total de 1.025 pollos indígenas, de los cuales el $90.7 \%$ fueron infestados con una o más especies de ectoparásitos. En este estudio se encontraron cuatro tipos de géneros de ectoparásitos, el $17.0 \%$ del total de pollos examinados fueron infestados con un solo género, mientras que el $73.9 \%$ fueron infestados con dos o más géneros diferentes. Entre los ectoparásitos encontrados, la infestación de piojos (85.8\%) fue la más prevalente seguida por ácaros $(70.4 \%)$, Pulgas (27.3\%) y garrapatas $(6.2 \%)$ en orden descendente de diseminación. En el estudio se identificaron diez especies diferentes de ectoparásitos, a saber, Menopon gallinae, Lipeurus caponis, Goniodes gigas, Cnemidocoptes mutans, Dermanyssus gallinae, especies de Epidermoptes, Laminosioptes cysticola, especies de Megninia, Echidnophaga gallinacean y Argas persicus. Menopon gallinae (50\%) se encontró con mayor frecuencia, mientras que las especies de Megninia (2,7\%) fueron las menos prevalentes. Los hallazgos de este estudio mostraron que las infestaciones de ectoparásitos eran altamente prevalentes entre las parvadas de pollos indígenas, lo que probablemente pueda afectar su productividad óptima. La prevención y el control rutinarios de los ectoparásitos deben fomentarse en las áreas de estudio.

Palabras clave: Pollos nativos, ectoparásitos, infestaciones, consejos de gobiernos locales seleccionados y estados en Nigeria.

\section{INTRODUCTION}

Village poultry production is an integral part of a balanced farming system; it has a unique position in the rural household economy supplying high quality protein to the family (Ahaotu et al., 2017a and Angyiereyiri et al., 2015). It also serves as a source of easily disposable petty income for the rural dwellers (Alders et al., 2009 and Ahaotu et al., 2016a). They require little labor intensity, affordable inputs and low initial investment compared to other livestock production activities (Ahaotu et al., 2018a). It is also reported that indigenous poultry play significant roles through their contribution to the cultural and social life of rural dwellers (Ahaotu et al., 2016b; Mwale and Masika, 2009). Among the village poultry species, indigenous 
chicken in Nigeria represents a significant part of the national and the rural economy in particular (Lawal et al., 2015 and Ogbuokiri et al., 2015).

Unfortunately, the majority of these chickens are maintained under traditional system with little or no inputs for housing, feeding or veterinary care (Geidam et al., 2011). These birds can easily be exposed to harsh environmental conditions or be infected with several types of diseases such as bacterial, viral, fungal and parasitic pathogens (Ahaotu et al., 2018b). Among various parasitic diseases, ectoparasites infestations are of great economic importance in indigenous chicken production systems (Firaol et al., 2014). They usually consume dead cells of the skin and tissue fluids, cause heavy morbidity by sucking blood, while other causes irritation to the birds, which adversely affects their economical productivity (Nyoni and Masika, 2012 and Onwuasor, 2017).

Ecto-parasitism has been identified as one of the major factors that threaten scavenging indigenous chicken production systems in developing countries (Ononiwu et al., 2017 and Zumani, 2011). Mortalities due to parasitic diseases is higher than those attributed to some poultry viral infectious diseases such Newcastle disease and fowl pox disease (Opara et al., 2014). Common ecto-parasites of village chickens range from lice, mites, fleas and ticks (Nnadi and George, 2010). Some of the ectoparasites, especially tick and mites acts as vectors of poultry diseases such as Pastuerellosis, Fowl Pox, Newcastle disease and possibly chlamydia (Moyo et al., 2015).

Parasitic infection has been known to result in immunosuppression, especially in response to vaccines against some poultry diseases (Ahaotu et al., 2018c). High losses of indigenous chickens due to diseases pose a serious threat to food security and livelihood of many rural families (Musa et al., 2008). It is believed that understanding the nature of parasitic diseases of birds will assist in devising the appropriate measures to improve the health and utility of these birds (Amede et al., 2011). Ectoparasites may be a considerable constraint to Nigerians efforts to achieve increased production of indigenous chickens and products to enhance food security, poverty alleviation and improvement of job creation among youths so as to meet the demand of the fast growing populace of the country. Information available on the widespread of ectoparasites in indigenous chickens in some parts of Nigeria are those of Usman et al. (2012) in Sokoto State northwestern Nigeria, Ekpo et al. (2010) in Abeokuta, Ogun State, South Western Nigeria, Eneanya et al. (2008) in Akwa - Anambra State, South Eastern Nigeria and Biu et al. (2012) in Maiduguri North Eastern Nigeria.

At present, no routine government policy and activity is in place for routine control and prevention of indigenous chicken ecto-parasites in Nigeria. Adequate control practice of ectoparasites in rural areas is not carried out. Research on ecto-parasitism of livestock has mostly been concentrated on ticks and biting flies in ruminants (Cattle, sheep and goats) because of economic significance of ecto-parasite borne diseases (Adang et al., 2015). Specific objectives 
are to determine the prevalence of ecto-parasites in village chickens and to evaluate the economic significance of ecto-parasites infestation in Nigeria.

\section{MATERIALS AND METHODS}

The study was carried out at Akwa-Ibom, Ogun, Anambra, Sokoto, Rivers, Oyo, Kano and Imo selected states in Nigeria. The randomly selected states are densely populated. The states are located within the lowland coastal plain of Nigeria. Akwa-Ibom State lies between latitudes $4^{\circ} 32^{1}$ and $5^{\circ} 33^{1}$ North and longitudes $7^{\circ} 35^{1}$ and $8^{\circ} 25^{1}$ East; Bayelsa State lies within the latitude of $4^{\circ} 15^{1}$ and $5^{0} 23^{1}$, longitude $5^{0} 15^{1}$ and $6^{0} 45^{1}$ and longitude $05^{0} 22^{1}$ West while Kano State lies between latitude $13^{\circ} \mathrm{N}$ in the North and $11^{\circ} \mathrm{N}$ in the South and longitude $8^{\circ} \mathrm{W}$ in the West and $10^{\circ} \mathrm{E}$ in the East. The major occupations of the people are trading, public service and farming. Many do combine farming with other occupation like tailoring, masonry and transportation. A total of 1200 questionnaires were distributed among randomly selected participants in selected communities and states in Nigeria. The selected local government councils were shown in Table 1.

Table 1: Selected Study Sites

$\begin{array}{llr}\text { Sn } & \text { States } & \text { Local Government Councils } \\ 1 . & \text { Akwa - Ibom } & \text { Eket, Ikono and Mbo } \\ 2 . & \text { Ogun } & \text { Ifo, Ikenna and Odeda } \\ 3 . & \text { Anambra } & \text { Aguata, Dunukofia and Ogbaru } \\ 4 . & \text { Sokoto } & \text { Bodinga, Rabah and Tureta } \\ 5 . & \text { Rivers } & \text { Okrika, Eleme and Gokana } \\ 6 . & \text { Oyo } & \text { Akinyele, Irepo and Iwajowa } \\ \text { 7. Kano } & & \text { Dawakin, Kiru and Tudun Wada } \\ \text { 8. } & \text { Imo } & \text { Ngor Okpala, Obowo and Orsu } \\ 9 . & \text { Zamfara } & \text { Bungudu, Maradun and Zurimi } \\ \text { 10. } & \text { Ondo } & \text { Idanre, Ilaje and Owo }\end{array}$

Fifty questionnaires were distributed per local government council and 150 distributed per town. Out of the one thousand two hundred questionnaires distributed, only seven hundred and twenty (720) were collected back for analysis. The smallholder poultry farmers responded to 700 questionnaires and the data obtained from the study were analyzed using descriptive statistics such as range, mean, frequency and percentages. 
Sampling procedure: one thousand and twenty five village chickens which comprises of both sexes and various ages were sampled from randomly selected states and local government councils in Nigeria. Household with moderately large numbers of village chickens population and that were willing to voluntarily cooperate with the sampling procedures were randomly selected and included in the study, while some of the selected farmers were tipped with incentives before allowing the use of their birds for the sampling procedures of ecto-parasites infestations. Samplings were carried out for a period of six months on weekly basis. Ecto-parasites were collected from the body and skin of each bird and not from the ground in order to minimize accidental collections of other arthropods that do not actually parasitize birds. Examinations for ecto-parasitic infestations were carried out early in the morning and in the evening.

Parasitological procedures: investigation for ecto-parasites infestation in birds were performed by carefully parting feathers horizontally against the anatomical direction of alignment so as to expose parasites and allow visual inspection of the skin and other parts of the birds' body (Yacob et al., 2009). Ecto- parasites were collected from the body of the birds using the forceps-picking and feather-brushing methods described by Angyiereyiri et al. (2015). The entire body of the bird was thoroughly inspected and gently brushed with a fine soft brush; special attention was paid to under the wings as recommended by Angyiereyiri et al. (2015). In the case of strong attachment and embedded ticks, the ticks were removed using chloroform by dabbing the ticks and the skin. Lice, fleas and mites were collected by dipping a brush in ethanol before combing and brushing the feather and skin of the bird onto a white blotting paper. (Hobbenaghi et al., 2012). The parasites collected were preserved in $70 \%$ ethanol in well labeled glass vials and other data were recorded accordingly.

Ecto-parasite identification: ticks, lice, fleas and mites were identified according to keys and descriptions by Ruedisueli and Manship, (2006). Ticks were examined under the light microscope and each morphological character was measured and recorded for identification. Lice, fleas and mites were heated in $5 \% \mathrm{KOH}$ for $20 \mathrm{~min}$, washed and dehydrated by treating them with ethanol, then cleared in xylene for $20 \mathrm{~min}$ and mounted on the light microscope.

\section{RESULTS AND DISCUSSIONS}

Table 2 shows the results of the prevalence ecto-parasites infestation in randomly selected Local Government Councils and States in Nigeria according to study locations. Out of the thirty different study locations visited for village chicken examination in Nigeria, the following prevalent rates were encountered in descending order: Imo State (97.2\%), Akwa Ibom State (94.8\%), Anambra State (94.1\%), Rivers State (93.0\%), Zamfara State (91.5\%), Ondo State $(89.0 \%)$, Sokoto State $(89.9 \%)$, Ogun State $(88.6 \%)$, Oyo State $(86.5 \%)$ and Kano State $(80.9 \%)$ respectively. 
Sustainability, Agri, Food and Environmental Research, (ISSN: 0719-3726), 7(2), 2019: 17-31

http://dx.doi.org

Table 1. Prevalence of Ecto-parasites in Village Chickens in Randomly Selected Local Government Councils and States in Nigeria.

\begin{tabular}{|c|c|c|c|c|c|}
\hline $\begin{array}{l}\text { Study location } \\
\text { examined } n=1025\end{array}$ & & $\begin{array}{l}\text { Number of chickens } \\
\text { chickens affected }\end{array}$ & & $\begin{array}{l}\text { Number of } \\
(\%)\end{array}$ & Relative Prevalence \\
\hline $\begin{array}{l}\text { Akwa-Ibom State } \\
\text { (Eket, Ikono and Mt }\end{array}$ & 95 & & 91 & & 94.8 \\
\hline $\begin{array}{l}\text { Ogun } \\
\text { (Ifo, Ikenna and Od }\end{array}$ & $\begin{array}{l}105 \\
\text { eda) }\end{array}$ & & 93 & & 68.6 \\
\hline $\begin{array}{l}\text { Anambra } \\
\text { (Aguata, Dunukofia } \\
\text { and Ogbaru) }\end{array}$ & 101 & & 95 & & 94.1 \\
\hline $\begin{array}{l}\text { Sokoto } \\
\text { (Bodinga, Rabah } \\
\text { and Tureta) }\end{array}$ & 99 & & 89 & & 89.9 \\
\hline $\begin{array}{l}\text { Rivers } \\
\text { (Okrika, Eleme } \\
\text { and Gokana) }\end{array}$ & 114 & & 106 & & 93.0 \\
\hline $\begin{array}{l}\text { Oyo } \\
\text { (Akinyele, Irepo } \\
\text { and Iwajowa) }\end{array}$ & 96 & & 83 & & 86.5 \\
\hline $\begin{array}{l}\text { Kano } \\
\text { (Dawakin, Kiru } \\
\text { and Tudun Wada) }\end{array}$ & 89 & & 72 & & 80.9 \\
\hline $\begin{array}{l}\text { Imo } \\
\text { (Ngor Okpala, Obov } \\
\text { and Orsu) }\end{array}$ & 108 & & 105 & & 97.2 \\
\hline $\begin{array}{l}\text { Zamfara } \\
\text { (Bungudu, Maradun } \\
\text { and Zurimi) }\end{array}$ & 117 & & 107 & & 91.5 \\
\hline $\begin{array}{l}\text { Ondo } \\
\text { (Idanre, Ilaje } \\
\text { and Owo) }\end{array}$ & 100 & & 89 & & 89.0 \\
\hline Total & 1025 & & 930 & & 90.7 \\
\hline
\end{tabular}

Table 2 shows the results of the ecto-parasites infestation in randomly selected Local Government Councils and States in Nigeria. Out of the total one thousand and twenty five village chickens examined, nine hundred and thirty (90.7\%) were infected with one or more types of ecto-parasites, namely; lice, fleas, mites and ticks. In single infestation, $33.3 \%$ birds 
had lice, $1.2 \%$ fleas, $1.7 \%$ mites and $0.8 \%$ had ticks. Of the 930 infested birds, $17.0 \%$ had single, while $73.9 \%$ had mixed infestations. Mixed infestations of ecto-parasites was encountered as follows: lice and fleas (5.1\%); lice and mites (45.0\%), fleas and mites (1.4\%); Lice, Fleas and Mites (17.0\%), Lice, Mites and Ticks (2.7\%), Lice, Fleas, Ticks and Mites (2.7\%).

Table 3 shows the results of the prevalence of different species of ecto-parasites according to the infested anatomic site on village chickens in randomly selected Local Government Councils and States in Nigeria. Lice (85.8\%) were the most prevalent ecto-parasite encountered, while mites (70.4\%), flea (27.3\%) and ticks $(6.2 \%)$ were also encountered in this study. In species specific prevalence, the prevalent rates encountered was as follows in descending order: Menopon gallinae (50.0\%) which were seen on the feather shafts and all over the body of examined birds, Cnemidocoptes mutans (33.9\%) found around the lower limbs (non-feathered areas), Echidnophaga gallinacean (27.3\%) around the Comb, wattles, eyes and ears, Lipeurus caponis $(22.1 \%)$ found under the large wing feathers, Epidermoptes species $(16.9 \%)$ found on some parts of the body, Dermanyssus gallinae (13.9\%) found on entire body, Goniodes gigas (13.6\%) found within body feathers, Argas persicus (6.2\%) found around the ventral abdominal area and beneath the wings, Laminosioptes cysticola (3.1\%) on subcutaneous tissue and Megninia species (2.7\%) found on the on feathers (quills).

Table 2. Ecto-parasites encountered according to parasitic infestation (single or mixed infestations) in randomly selected Local Government Councils and States in Nigeria.

\begin{tabular}{|c|c|c|c|}
\hline \multirow[t]{2}{*}{ Parasitic Infestation } & Type of Ecto-Parasite & & Number of Chickens Relative Prevalence (\%) \\
\hline & Encountered & Affected (y) & $(y / 1025) \times 100$ \\
\hline & Lice & 136 & 13.3 \\
\hline \multirow[t]{5}{*}{ Single Infestation } & Fleas & 12 & 1.2 \\
\hline & Mites & 17 & 1.7 \\
\hline & Ticks & 8 & 0.8 \\
\hline & Lice and Fleas & 52 & 5.1 \\
\hline & Lice and Mites & 461 & 45.0 \\
\hline \multirow[t]{3}{*}{ Mixed Infestations } & Fleas and Mites & 14 & 1.4 \\
\hline & Lice, Fleas and Mites & 174 & 17.0 \\
\hline & Lice, Mites and Ticks & 28 & 2.7 \\
\hline \multicolumn{2}{|c|}{ Lice, Fleas, Ticks and Mites } & 28 & 2.7 \\
\hline Total & & 930 & 90.7 \\
\hline
\end{tabular}


Table 3. Prevalence of different species of ecto-parasites according to the infested anatomic site on village chickens in randomly selected Local Government Councils and States in Nigeria.

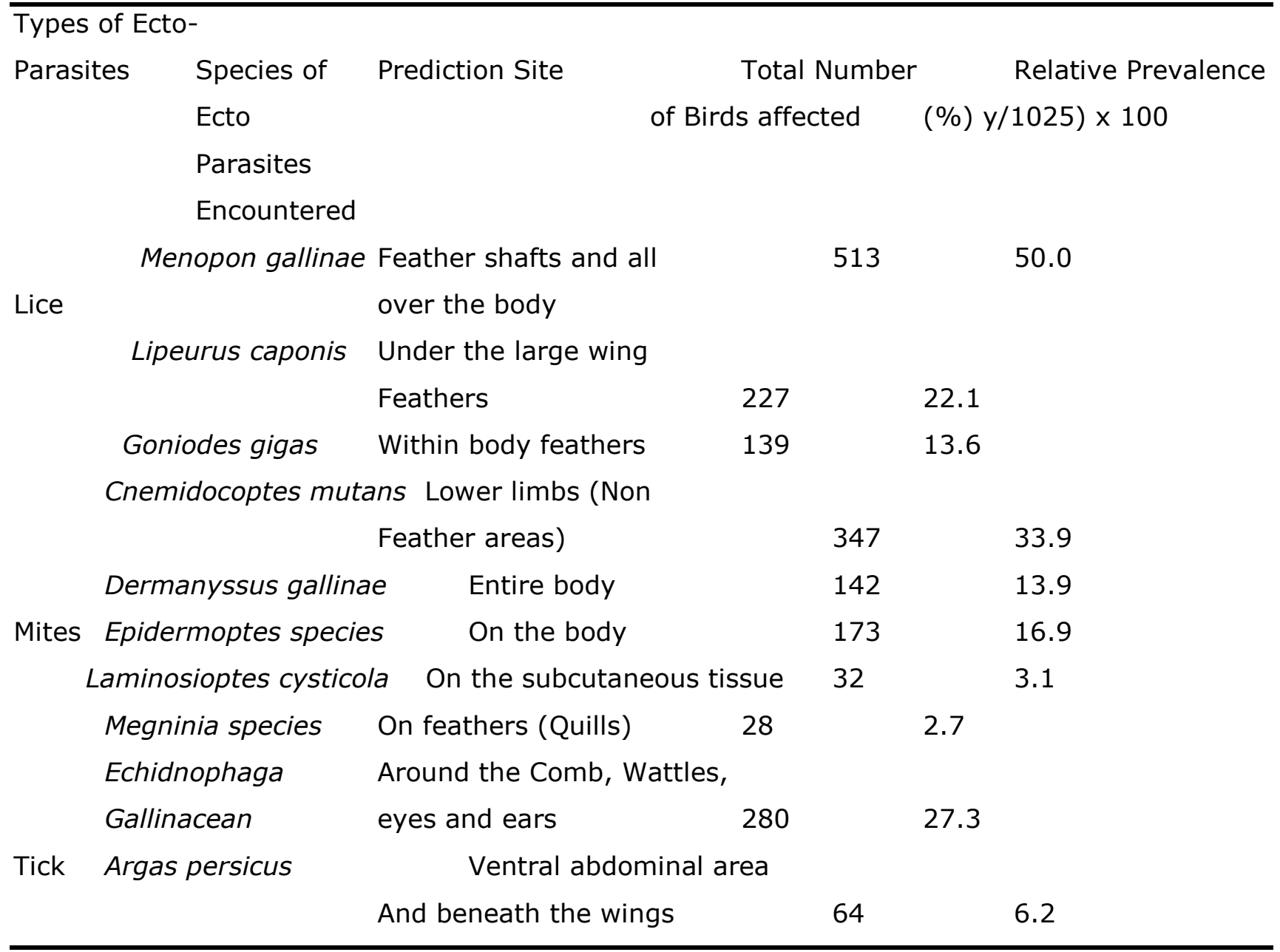

The present study further revealed the occurrence of various species of ecto-parasites within different external anatomical parts of village chickens following thorough body examination of each randomly sampled bird. It has been established that ecto-parasites are important constraints to village chickens production system. This study have revealed varying prevalent rate of ecto-parasitism in village chickens with higher prevalent rates of $97.2 \%$, 94.8\% and $94.1 \%$ encountered in Imo State, Akwa - Ibom State and Anambra State respectively while $86.5 \%$ and $80.9 \%$ prevalent rates were found in Oyo State. Four types of ecto-parasites genera were encountered in this present study in all the study areas. The prevalence of ecto-parasites infestation encountered in village chicken production system in this study were $85.8 \%$ lice, $70.4 \%$ mite, $27.3 \%$ flea and $6.2 \%$ tick of different species. This finding is consistent with the finding of Sabuni et al. (2010). 
Ecto-parasites were found on different body parts of the examined chickens. Wherever part of the birds' body ecto-parasites infest, they cause lot of irritations by their biting and sucking activities. This may distracts the birds from its normal activities such as feeding; incubation of eggs and such parasites also serves as transmitters of blood parasitic diseases (Hobbenaghi et al., 2012).

The observed overall prevalence rate of ecto-parasites $(90.7 \%)$ in village chickens from the study areas were considerably high, which indicated that ecto-parasite infestation is a common problem among this class of poultry in the study areas. This high prevalence of ectoparasitism may be associated with the provision of poor housing facilities for village chickens in some of the study areas, which creates conducive environment for the breeding of the diverse parasitic arthropods.

It have been well established that ecto-parasitic infestation has direct or indirect effects on the productivity of village chickens in developing countries of Africa such as Tanzania (Swai et al., 2009); Ethiopia (Tolossa and Tafesse, 2013); Ghana (Angyiereyiri et al., 2015); Zimbabwe (Mukaratirwa and Hove, 2009); Nigeria (Bala et al., 2011 and Ogbuokiri et al, 2011a). However, varying high prevalence rate of $91.5 \%$ (Belihu et al., 2010), 86.67\% (Shanta et al., 2006), 83.85\% (Mulugeta et al., 2013) and 100\% (Bala et al., 2011) have been reported in different studies. The difference between our findings and that of the other previous researches may be due to breed or ecotypes of birds, seasonality of infection, management / husbandry systems, agro-ecological, and implemented methods of the parasitic control (Mekuria and Gezahegn, 2010).

This study was conducted during rainy season towards early dry season of the year (August to January) while others might have conducted ecto-parasites samples collection during the dry season of the year (Belihu et al., 2010) or during heavy rainy season (Ogbuokiri et al., 2011b). Ecto-parasites infected chickens in the present study were found to harbour single or mixed infestation of ecto-parasite species. $17.0 \%$ of the total examined chickens were found to be infested with single species of ecto-parasites while $73.9 \%$ were infested with mixed ectoparasitic infestation. The mixed ecto-parasitic infestation of chickens found in this study was lower than $81 \%$ ecto-parasitic infestation reported by Al-Saffar and Al-Mawla (2008) in Iran but higher than 48.21\% reported by Firaol et al. (2014) and 67.4\% reported by Amede et al. (2011) in Ethiopia. However, the single infestation of $19 \%$ reported by Al-Saffar and Al-Mawla (2008) was slightly higher than that of our findings. The observed variation in the proportion of single and mixed infestation in village chickens would be related to difference of implementation of management system and whether or not strategic ecto-parasitic control measures were adopted in the various study areas.

Ten species of ecto-parasites, namely Menopon gallinae, Lipeurus caponis, Goniodes gigas (Lice); Cnemidocoptes mutans, Dermanyssus gallinae, Epidermoptes species, Laminosioptes cysticola, Megninia species (Mites); Echidnophaga gallinacean (Flea) and Argas 
persicus (Tick) were identified in the present study. This finds is consistent with those of Bala et al. (2011) and Mukaratirwa and Hove (2009) that reported ten and eleven different ectoparasites respectively in village chickens during a similar study. This indicates widespread of these ecto-parasite species in village chickens in most of the African countries including Nigeria. Although variations in the findings might be due to the numbers of birds examined, type of management system practice, climatic and geographic (altitudinal) difference among the various study areas. Among the identified ecto-parasite species found on the examined village chickens, Menopon gallinae was most frequently identified (50\%) species while Megninia species (2.7\%) was the least encountered ecto-parasite species.

The prevalence of $22.1 \%$ of Lipeurus caponis encountered in this study is higher than $5 \%$ reported by Bala et al. (2011) and $0.67 \%$ report of Belihu et al. (2010), but lower than 32\% and $48 \%$ reported by Shanta et al. (2006) respectively. Prevalence of Goniodes gigas (13.6\%) is slightly lower than $14.5 \%$ reported by Audi and Asmau (2014) but higher than 6.5\% reported by Moyo et al. (2015) who carried out similar study. The finding of Laminosioptes cysticola (3.1\%) encountered in this study is higher than $0.4 \%$ reported by Mukaratirwa and Hove (2009). Megninia species (2.7\%) encountered in this study have rarely been reported in village chickens in Nigeria but have been reported in Kenya by Sabuni et al. (2010). The finding of ecto-parasites of unique species in village chickens population may possibly occur where this class of birds is reared within the same environments or enclosures with other livestock species (cattle, sheep, goats, rabbits) (Asadollahi et al., 2014; Ahaotu et al., 2017d), companion animals (cats, dogs) (Shitta et al., 2011 and Adamu et al., 2012 ), wild domesticated birds (Ostriches, doves, peacocks or parrots) or other domestic birds species (guinea fowl, turkeys, ducks or pigeon) especially where these animals are reared under unhygienic husbandry systems (Ahaotu et al., 2017c).

Widespread of Echidnophaga gallinacean (27.3\%) encountered in this study is lower than $50.7 \% ; 71.9 \% ; 44.4 \%$ and $51.16 \%$ reported by (Moyo et al. 2015, Mukaratirwa and Hove 2009, Firaol et al. 2014 and Belihu et al. 2010) respectively, but higher than $9.4 \%$ and $0.89 \%$ reported by (Bala et al. 2011 and Biu et al. 2012). Argas persicus (6.2\%) was the only tick species of birds encountered in this study. This finding was consistent with the findings of Mukaratirwa and Hove (2009) who recorded $8.8 \%, 4.97 \%$ and $5.2 \%$ respectively in a similar study. However, Bunza et al. (2008) reported 62.2\% prevalence of Argas persicus in village chickens in a survey to study the ticks in domesticated birds. Considering the respective findings reported in the various works, the difference might be due to the numbers of birds examined during various study, type of management system practice, climatic and geographic (altitudinal) difference among the various study areas.

As conclusion, village poultry production has formed an integral part of livestock production systems in most developing countries including Nigeria. They serves as source of petty cash and high quality protein derived respectively from sales and consumption of poultry 
products (meat and eggs), yet this potential lucrative enterprise is still the most neglected in terms of management, husbandry practice and particularly veterinary health care, especially in rural communities where majority of the village chickens are reared. Generally, the finding of the present study clearly indicated that ecto-parasites infestations are highly prevalent in scavenging village chickens production and management system which is associated with inadequate hygienic system, poor husbandry and management, lack of Strategic ecto-parasites control practices. In most villages chicken production system, the economic importance of ectoparasites and the havoc caused by heavy infestation are generally overlooked by farmers. This may be reflected by low productivity and increased loss of the birds especially during period favourable to breeding of the parasites. Poor housing facilities can create hiding places for the parasite and this may jeopardize effort made toward control and treatment. It is assumed that arthropods in poultry houses can generate continuous infestation even following treatment of environment using insecticides.

\section{ACKNOWLEDGEMENTS}

The authors wish to acknowledge the management and staff of Osho Resources and Information Services, Lagos State, Nigeria, for their unwavering support, guidance and expertise during the project process. Great appreciation is extended to Ms Julie Nwachukwu who kindly devoted time and expertise in data analysis.

\section{REFERENCES}

Adamu, N.B, Adamu J.Y and Salisu .L 2012. Prevalence of ecto-, endo- and haemoparasites in slaughtered dogs in Maiduguri, Nigeria. Revue de Medecine Veterinaire, 4:178-182.

Adang, K.L, Ayuba .J and Yoriyo K.P 2015. Ectoparasites of Sheep (Ovisaries L.) and Goats (Capra hirusL.) in Gombe, Gombe State, Nigeria. Pakistan Journal of Biological Sciences 18: 224-231.

Ahaotu, E.O, Onyegbula. T and Ahaotu, Esther .O 2018a. Haematological Characteristics and Organoleptic Test of Feeding Different Levels of Pawpaw (Carica papaya) Leaf Meal on Finisher Broiler Birds. International Journal of Animal and Veterinary Sciences, 5: 10-14

Ahaotu, EO, Kwushue $\mathrm{V}$ and Ahaotu Esther .O 2018b. Performance Implications of Feeding Different Levels of Pawpaw (Carica papaya) Leaf Meal on Finisher Broiler Birds. Journal of Poultry Science and Technology 6: 1-4

Ahaotu E.O, Amadinze .C and Ahaotu Esther .O 2018c. Carcass and Organ Weight Indices of Feeding Different Levels of Pawpaw Leaf Meal (Carica papaya) on Finisher Broiler Birds. Journal of Meat Science and Technology, 6: 1-4. 
Ahaotu, E.O, C.N. Nze, Esther .O. Ahaotu and A. Amalahu 2017a. Nutritional Evaluation of graded levels of unripe plantain peel (Musa paradisca) meal on the performance of grower Japanese quails (Coturnix). Proc. 42 ${ }^{\text {nd }}$ Conf., Nig. Soc. for Anim. Prod. $26-30$ March, 2017. Pp 487 - 490.

Ahaotu, E.O, B.U. Ekenyem and E. Aggrey 2017b. Sustainability of sweet orange (Citrus sinensis) peel meal on the performance of finisher Broilers. Journal of Agriculture Sciences and Practices, 2: 27-32.

Ahaotu, E. O., Ihenacho, R. A., Ike, A. and Ihenacho, A. C. 2017c. Socio-economic and management practices of Duck in Imo State. A study of Orlu Local Government Area, Imo State, Nigeria. Direct Journal of Agriculture and Food Science. 5 (6): 250-255.

Ahaotu, E.O, Ifut, O.J and A. Akinfemi 2017d. Characteristics of Small holder Sheep Production from Selected Local Government Councils and States in Nigeria. Proceedings of the $20^{\text {th }}$ Biennial Conference, Ghana Society of Animal Production (GSAP), 1-5 August, 2017 Sasakawa Centre, University of Cape Coast, Ghana. Pp 64-72.

Ahaotu, E.O, V.N. Okonkwo, K.C. Okorie and A. Akinfemi 2016a. Effect of Bambara Nut Sievate Supplemented Exogenous Enzymes on Haematology and Serum Biochemical Value of Finisher Broiler Birds. Book of Proceedings of Academic Conference on Positioning SubSaharan Africa for Development in the New Development. 22-23 $3^{\text {rd }}$ June, 2016, Cambridge Hall, University of Ghana, Legon Campus, Accra. Vol. 9 (1): 32 - 39.

Ahaotu, E.O V.N. Okonkwo, Ihenacho, R.A and Ebochuo, V.C 2016b. Performance and Carcass Characteristics of Finisher Broilers fed Brewer's dried grain supplemented with Exogenous Enzymes. Book of Proceedings of Academic Conference on Positioning Sub-Saharan Africa for Development in the New Development. 22-23 ${ }^{\text {rd }}$ June, 2016, Cambridge Hall, University of Ghana, Legon Campus, Accra. Vol. 9 (1): $200-208$.

Alders R.G, Spradbrow P.B and Young M.P (eds) 2009. Village chickens, poverty alleviation and the sustainable control of Newcastle disease. Proceedings of an international conference held in Dar es Salaam, Tanzania, 5-7 October 2005. ACIAR Proceedings No. 131, 235 pp.

Al-Saffar T.M and Al-Mawla E.D 2008. Some hematological changes in chickens infected with ectoparasites in Mosul. Iraqi Journal of Veterinary Sciences 22: 95-100.

Amede .Y, Tilahun .K and Bekele .M 2011. Prevalence of Ectoparasites in Haramaya University Intensive Poultry Farm. Global Veterinary, 7: 264-269.

Angyiereyiri E.D, Sackey .I and Bonu-Ire M.S.T 2015. Survey on Arthropod Ectoparasites on Goats and Domestic Fowls in Vunania, Navrongo, Ghana. Canandian Journal of Pure and Applied Sciences 9: 3371-3377.

Asadollahi .Z, Jalali R.M.H, Alborzi .A, Hamidinejat .H, Boroujeni M.P and Sazmand .A 2014. Study of cattle ixodid ticks in Khoozestan Province, South-West of Iran. Acarina, 22: 157160. 
Audi A.H and Asmau A.M 2014. Prevalence of bird Louse, MenacanthusCornutus (Pthiraptera: Amblycera) in Four Selected Poultry Farms in Kano State, Nigeria. Bayero Journal of Pure and Applied Sciences, 7:142 -146.

Bala A.Y, Anka S.A, Waziri .A and Shehu .H 2011. Preliminary Survey of Ectoparasites Infesting Chickens (Gallus domesticus) in Four Areas of Sokoto Metropolis. Nigerian Journal of Basic and Applied Sciences, 19: 173-180.

Belihu .K, Mamo .A, Lobago .F and Ayana .D 2010. Prevalence of Ectoparasites in Backyard Local Chickens in Three Agroecologic Zones of East Shoa in Ethiopia. Revue Méd. Vét: 160: 537-541.

Biu A.A, Ahmed H.A, Konto M and Paul B.T 2012. Survey of podoknemidokoptiasis in locally domesticated market chickens (Gallusgallusdomesticus) in Maiduguri, Nigeria. Journal of Medical Applied Biosciences 4: 39-46.

Bunza M.D.A, Yahaya M.M, Muhammed A.S and Saidu A.R 2008. A survey on ticks species infesting domestic birds sold at Sokoto central Market. Sokoto Journal of Veterinary Sciences, 7: 56 - 58

Deepali, C, Agnihotri K.R, and Katoch .R 2005. Incidence of ectoparasites in poultry in Palam valley of Himachal Pradesh. Journal of Veterinary Parasitology, 19:57-59.

Ekpo, U.F, Ogbooye A.A, Oluwole A.S and Takeet .M 2010. A preliminary survey on the parasites of Free range chicken in Abeokuta, Ogun State, Nigeria. Journal of Natural Sciences, Engineering and Technology, 9: 123-130.

Eneanya C.I, Amagba I.C, and Ikpeze 0.0 2008. Ectoparasitic fauna of poultry farms in Awka, Anambra, Nigeria. Inter. J. Zoonoses, 13: 93-97.

Firaol .T, Dagmawit .A, Askale .G, Solomon .S, Morka .D and Waktole .T 2014. Prevalence of Ectoparasite Infestation in Chicken in and Around Ambo Town, Ethiopia. Journal of Veterinary Sciences and Technology, 5: 1-5.

Geidam Y.A, Rabana J.L, Sanda K.A and Grema H.A 2011. A survey of Health and Management problems Associated with Rural Poultry Production in Gombe metropolis, North - eastern Nigeria. Sahel Journal of Veterinary Scienes, 10: $77-81$.

Hobbenaghi .R, Tavassoli .M, Alimehr .M, Shokrpoor .S and Ghorbanzadeghan .M 2012. Histopathological study of the mite biting (Dermanyssus gallinae) in poultry skin. Veterinary Research Forum 3: 205 - 208.

Lawal J.R, Hambali I.U, Jajere S.M, Bello A.M, Biu A.A and Musa .G 2015. Survey and Prevalence of Gastro-intestinal Cestodes in Village Chickens (Gallus gallusdomesticus) Slaughtered in Gombe Metropolis Poultry Dressing Slabs. International Journal of Livestock Research, 5: 21-27.

Mekuria .S and Gezahegn .E 2010. Prevalence of External parasite of poultry in intensive and backyard chicken farm at Wolayta Soddo town, Southern Ethiopia. Veterinary World, 3: 533-538. 
Moyo, S., Masika, P. J. and Moyo, B. 2015. A Diagnostic Survey of External Parasites of FreeRange chickens, in the rural areas of Eastern Cape, South Africa. International Journa of Agriculture Sciences and Veterinary Medicine, 3: 1 - 9.

Mukaratirwa .S and Hove .T 2009. A survey of ectoparasites, cestodes and management of free-range indigenous chickens in rural Zimbabwe. Tydskr. S. African Veterinary Verein 80: $188-191$.

Mulugeta .A, Chanie .M and Bogale .B 2013. Major Constraints of Village Poultry Production in Demba Gofa District of Southern Region, Ethiopia. British Journal of Poultry Sciences 2: $1-6$.

Mungube E.O, Baun S.M, Tenhagen B.A, Wamae L.W, Nzioka S.M, Muhammed .L and Nginyi J.M 2008. Prevalence of Parasites of the Local Scavenging Chickens in a Selected Semi-Arid Zone of Eastern Kenya", Trop. An. Health and Prod., 40:101-109.

Musa .U, Abdu P.A, Dafwang I.I, Edache J.A, Ahmed M.S, Bawa G.S, Karsin P.D and Emannaa P.E 2008. A survey of causes of mortality in some Local chicken flocks in Plateau state: In: Proceedings of the 33rd Annual Conference of the Nigeria Society of Animal Production (NSAP), pp.551 - 554.

Mwale, .M and Masika P.J 2009. Ethno-Veterinary Control of Parasites, Management and Role of Village Chickens in Rural Households of Centane District in the Eastern Cape, South Africa. Tropical Animal Health and Production, 41:1685-1693.

Nnadi, P.A and George S.O 2010. A cross-sectional survey on parasites of chickens in selected villages in the subhumid zones of southeastern Nigeria. Journal of Parasitological Research, 1-6.

Nyoni, N.M.B and Masika P.J 2012.Village Chicken Production Practices in the Amatola Basin of the Eastern Cape Province, South Africa. African Journal of Agriculture Research, 17: 2647-2652.

Ogbuokiri, U.D.E, M.C. Edih, V. Izuazu, Ahaotu, E.O and C.I. Okoli 2015. Effect of Infection with E. Necatrix on the Body Weight gains and Spermatogenesis in Broiler Breeder Males. International Journal of Tropical Agriculture and Food Systems. 9: 12-15.

Ogbuokiri, U.D.E, E.O. Ahaotu, M.C. Edih, S.H. Fitz- Coy and V.N. Acholonu 2011a. Effects of lesser species of chicken Eimeria (E. Hegani, E. Mivati, E. Praecox and E. Mitis) on body weight gain and spermatogenesis of broiler breeders. International Journal of Agriculture and Food Systems. 5: 135 - 137.

Ogbuokiri, U.D.E, C.M. Ayo - Enwerem, E.O. Ahaotu, M.C. Edih , I.C. Okoli, M.N. Opara and V.N. Acholonu 2011b. Comparative Resistance of three line crosses of Broiler Chickens to three species of Eimeria. Animal Production Research Advances, 7: 120 - 124.

Ononiwu, C.C, Ahaotu, E.O, V.N.Okonkwo, C.M. Ayo-Enwerem and H. Botchway 2017. Effects of Bambara Nut Sievate Fortified Exogenous Enzyme on Performance and Carcass Characteristics of Finisher Broiler Birds. Proceedings of the $20^{\text {th }}$ Biennial Conference, 
Ghana Society of Animal Production (GSAP), 1-5 August, 2017. Sasakawa Centre, University of Cape Coast, Ghana Pp 73-80.

Onwuasor, A. 2017. Prevalence and Economic Importance of Ectoparasites Infestation in Village Chickens (Gallus gallus domesticus) in Imo State, Nigeria. (A study of Oru East Local Government Council). ND Project, Department of Animal Production and Health Technology, Imo State Polytechnic Umuagwo, Nigeria. 49pp.

Opara, M.N, Osowa, D.K and Maxwell, J.A 2014. Blood and Gastrointestinal Parasites of Chickens and Turkeys Reared in the Tropical Rainforest Zone of Southeastern Nigeria. Open Journal of Veterinary Medicine 4: 308-313.

Ruedisueli, F.L and Manship, B 2006. Tick identification key. University of Lincoln. Available online at http://webpages.lincoln.ac.uk/fruedisueli/FRwebpages/ parasitology/Ticks/TIK/tick-key/softticks_adult.htm.

Sabuni, Z.A, Mbuthia, P.G, Maingi, N, Nyaga P.N, Njagi, L.W, Bebora, L .C and Michieka, J.N 2010. Prevalence of ectoparasites infestation in indigenous free-ranging village chickens in different agro-ecological zones in Kenya. Livestock Research for Rural Development 22 (11).

Shanta, I.S, Begon, N, Anisuzzaman, A.S, Bari, M and Karim, M.J 2006. Prevalence and clinicopathological effects of Ectoparasites in backyard poultry. Bangladesh Journal of Veterinary Medicine 4: 19-26.

Shitta, K.B, Arong, G.A, James-Rugu, N.N and Effanga, E.O 2011. Seasonal variation in the abundance and distribution of Ixodid Ticks on Mongrel, Alsatian and Mixed breeds of dogs (canis familiaris) in Jos, Plateau State north central Nigeria. World Journal of Science and Technology, 1: 24-29.

Swai, E, Kessy, S.M, Sanka, P, Banga, S and Kaaya, J.E 2009. A survey on Ectoparasites and haemoparasites of free-range indigenous chickens of Northern Tanzania, Tanzania, 22:9.

Tolossa, Y.H and Tafesse, H.A 2013. Occurrence of ectoparasites and gastro-intestinal helminthes infections in Fayoumi chickens (Gallus gallusFayoumi) in DebreZeit Agricultural Research Center Poultry Farm, Oromia region, Ethiopia. Journal of Veterinary Medicine and Health, 5: 107-112.

Usman, M, Fabiyi, J.P, Mohammed, A.A, Mera, U.M, Mahmuda, A, Alayande, M.O, Lawal, M.D and Danmaigoro, A 2012. Ectoparasites and haemoparasites of chickens in sokoto, northwestern Nigeria. Sci. J. Zoology (2012) 1(3) 74-78.

Yacob, H.T, Ziad, D and Shafi, A.K.B 2009. Ectoparasites and gastrointestinal helminths of chickens of three agro-climatic zones in Oromia Region, Ethiopia. Animal Biology 59: 289-297.

Zumani, B 2011. Ectoparasites of indigenous Malawi chickens. Australian Journal of Basic and Applied Sciences, 5: 1454-1460. 